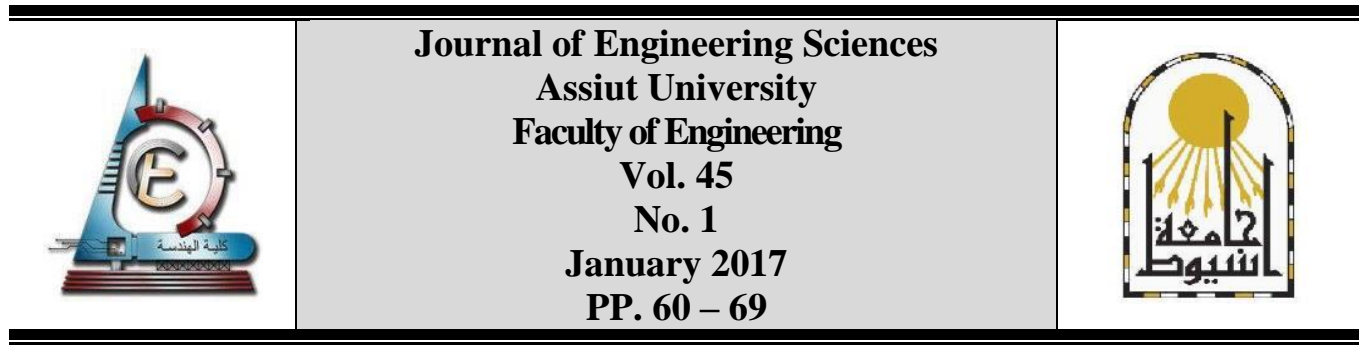

\title{
MEASUREMENT OF TENSILE PROPERTIES OF WELDED DISSIMILAR MATERIAL AT HIGH STRAIN RATE USING SPLIT HOPKINSON PRESSURE BAR ARRANGEMENT
}

\author{
H. M. Abdrahman, W. M. Khairaldien, A. A. Khalil \\ Department of Mechanical Eng., Faculty of Engineering, Assiut University, Assiut, Egypt
}

Received 10 November 2016; Accepted 21 December 2016

\begin{abstract}
Modern industrial and constructional applications require clear understanding of engineering material behavior under dynamic loading conditions especially for junction with dissimilar material. The most accurate method available for studying dynamic behavior accurately Split Hopkinson, however the compression nature of the test hinder the usage of this technique of split Hopkinson pressure bars which was designed to characterize compressive load material behavior. Many trial were made to modify SHPB gain the capability of loading samples in uniaxial tension using different construction modifications. However most of these trails failed to provide the adequate condition of wave motions and neglected the losses due to geometrical arrangement. In this work a simple method was proposed and executed to produce a tensile wave in the Hopkinson bar and use it to measure the tensile properties of material. The uniaxial tension load was applied with the help of a double cone opposites to each other that transfer the compression wave into a tensile wave through two cone ends that hit a hollow cylinder with machine cone ends holes the widen when the bars hit it with a compression wave and transfer the compression wave into a tension wave. The specimen used was a bimetal welded specimen which was tested under loading rates up to $500 \mathrm{~s}^{-1}$. The results showed a similarity in performance compared to static test but at a much higher load and at very low plastic deformation. The microstructure examination of the broken specimen shows a small ductile fracture surface and in some loading rates a cup and cone formation tendency.
\end{abstract}

\section{Introduction}

Rapid technology development produces a need to understand the behavior of engineering constructions under severe loading rates conditions such as cars, trains, building ...etc. This generates a great need to understand the constructional material behavior under high loading rates.

SHPB is capable of measuring the mechanical properties at high strain rate up to $10^{3} \mathrm{~s}^{-}$ ${ }^{1}[1]$, however the nature of the setup is to induce a compression wave while most of properties needed to be characterized are tensile in nature.

\footnotetext{
* Corresponding author.

E-mail address:hosh_mosa@yahoo.com
} 
Many trials have been made to characterize dynamic properties using SHPB. Lindholm and Yeakley [2] used SHPB to study materials in tension. Their setup utilized a "hat" type specimen sandwiched between a solid incident bar and a tubular transmitter bar.

Rotbaum and Rittel [3] prepared a modified version of the SHPB in which the load were applied using a $400 \mathrm{~mm}$ long tubular projectile and the air gun in an opposite position. However their setup was only capable of applying low magnitude force due to the nature of the tube projectile and motion difficulties.

M. Sasso, et al. [4] used reflected wave instead of the transmitted wave in loading the specimen. The compressive wave was transmitted from the incident bar to the transmitted bar using a capsule sleeve surrounding the tensile specimen. A very short specimen geometry was used to avoid buckling during the compression wave they assumed that the capsule absorbed all of the compression wave without affecting the specimen mechanical properties which is very difficult to achieve because of the difficulty in adjusting the capsule locking around the specimen.

Ogawa [5] used a setup in which the incident bar had some type of an anvil on the impacting end. A cylinder traveled along the incident bar and contacted the anvil. The impact resulted in a tensile pressure pulse in the incident bar loading the specimen to failure.

In this work a new proposed innovative method to convert compression wave into tensile wave using double wedge action design. The impact tension tests are conducted using the tensile version of the Split Hopkinson pressure bar consisting of striker, incident and transmitted bars.

When the striker bar hits the incident bar, it generates a stress wave that monitored at a strain gauge station positioned at the middle of the bar. At the end of the incident bar and the beginning of the transmitted bar installed two cone ends and tensile specimen which will allow suitable margin of reading to represent the load displacement curve of the material

\section{Experimental work}

\subsection{Material and specimen preparation}

The specimen (many specimens was tested) was made from two halves to be welded together. The first half is made from steel 37 (low carbon steel) with dimension (50mm long, $10 \mathrm{~mm}$ diameter), while the second half is made from stainless steel 316 (austenitic stainless steel) as low carbon steel half with dimensions $(50 \mathrm{~mm}$ long, $10 \mathrm{~mm}$ diameter) and the chemical composite described in the table (1). The two halves of the specimen were welded using a special fixation shown in the figure (1). The two halves were welded using shield metal arc welding using stainless E309L welding rod $\varphi 2 \mathrm{~mm}$. The welded specimen was then machined by using a lathe machine (cutoff tool ,left hand turning tool, right hand turning tool threading tool) to reach the dimension according to (ASTM E8/ E8M standard) shown in Fig. (2) 


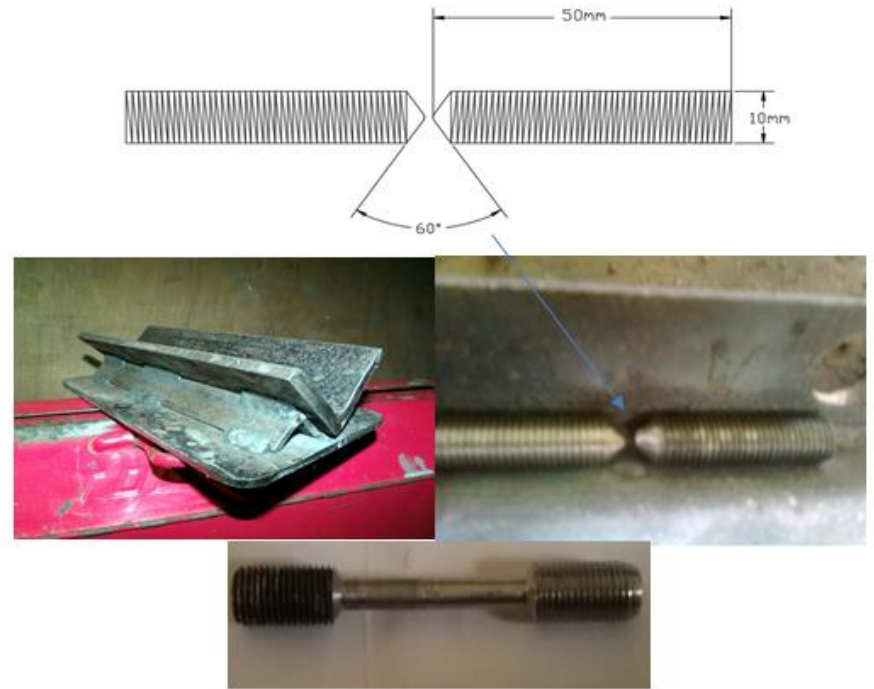

Fig. 1. specimen to manufactring

Table 1.

specimen halves chemical composition

\begin{tabular}{|c|c|c|c|c|c|c|c|}
\hline \multicolumn{2}{|c|}{$\begin{array}{l}\text { Carbon steel } \\
\text { composition }\end{array}$} & \multicolumn{7}{c|}{ Stainless steel composition } \\
\hline constituent & Wt. (\%) & constituent & Wt. (\%) & constituent & Wt. (\%) & constituent & Wt. (\%) \\
\hline $\mathrm{Si}$ & $0.15 \%$ & $\mathrm{C}$ & 0.0265 & $\mathrm{~V}$ & 0.0675 & $\mathrm{Ti}$ & 0.00459 \\
\hline $\mathrm{Cr}$ & $0.015 \%$ & $\mathrm{Si}$ & 0.375 & $\mathrm{~Pb}$ & 0.003 & $\mathrm{~W}$ & 0.07 \\
\hline $\mathrm{Ni}$ & $0.03 \%$ & $\mathrm{Mn}$ & 1.7 & $\mathrm{Cu}$ & 0.411 & $\mathrm{As}$ & 0.0005 \\
\hline $\mathrm{Mo}$ & $0.01 \%$ & $\mathrm{P}$ & 0.0003 & $\mathrm{Cr}$ & 16.54 & $\mathrm{~B}$ & 0.0001 \\
\hline $\mathrm{C}$ & $0.04 \%$ & $\mathrm{~S}$ & 0.00758 & $\mathrm{Mo}$ & 2.28 & $\mathrm{Fe}$ & 68.54 \\
\hline $\mathrm{S}$ & $0.01 \%$ & $\mathrm{Al}$ & 0.0136 & $\mathrm{Ni}$ & 9.71 & & \\
\hline $\mathrm{Fe}$ & $99.745 \%$ & $\mathrm{Co}$ & 0.247 & $\mathrm{Nb}$ & 0.017 & & \\
\hline
\end{tabular}

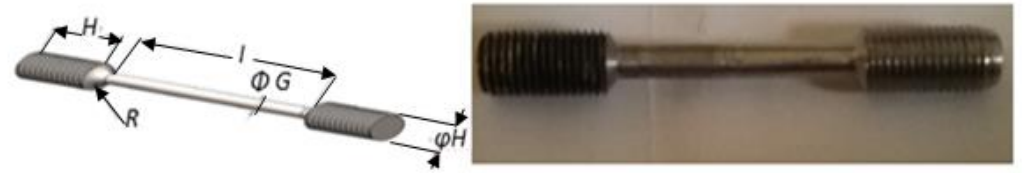

\begin{tabular}{|c|c|c|c|c|}
\hline$H$ in mm & $R$ in $\mathrm{mm}$ & $\varphi \mathrm{H}$ in $\mathrm{mm}$ & $\phi$ G in $\mathrm{mm}$ & $l$ in $\mathrm{mm}$ \\
\hline 25 & $\mathbf{3}$ & $\mathbf{1 0}$ & $\mathbf{4}$ & 44 \\
\hline
\end{tabular}

Fig. 2. Dimension of impact tension specimen with thread

\subsection{Static tensile test}

The tensile test was performed using a tensile testing machine model (universal testing machine) WDW-300 and the obtained stress strain curve is shown in fig (3) and the mechanical properties obtained are listed in table (2). The location of failure happened in the fusion zone and the Fracture show dimples in many areas, indicating ductility fracture shown in fig $(4,5$, and 6$)$. 


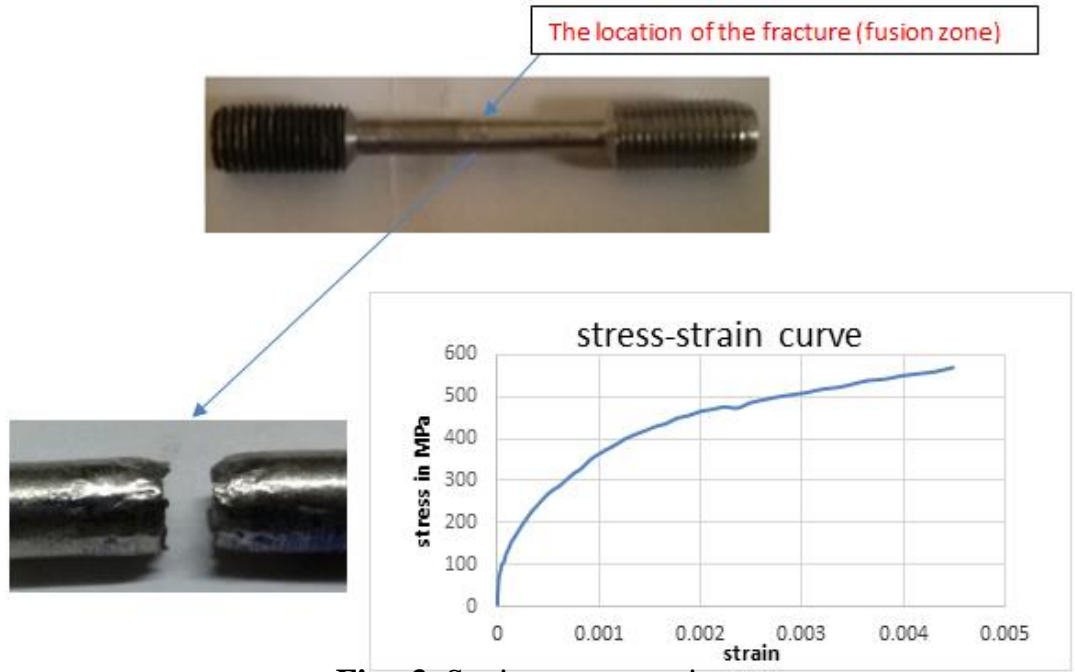

Fig.. 3. Static - stress strain curve

Table 2.

The mechanical properties of specimen

\begin{tabular}{|l|l|}
\hline \multicolumn{1}{|c|}{ Description } & Result \\
\hline Diameter d0 & $4.92 \mathrm{~mm}$ \\
\hline Start section S0 & $19.01 \mathrm{~mm}^{2}$ \\
\hline E-Modulus E & $200 \mathrm{GPa}$ \\
\hline Load max Fm & $10.65 \mathrm{kN}$ \\
\hline Tensile strength Rm & $560.33 \mathrm{MPa}$ \\
\hline
\end{tabular}
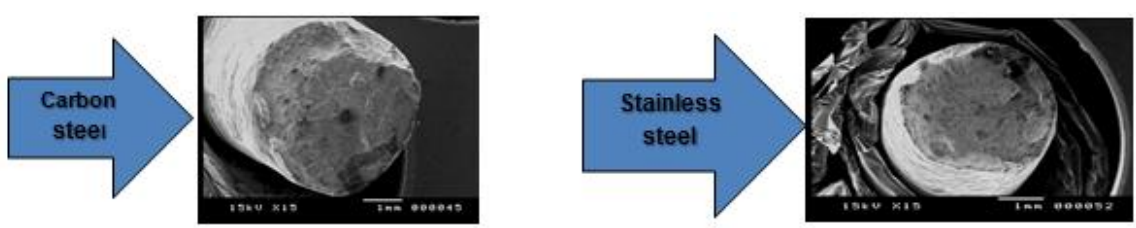

Fig. 4. Specimen broken ends
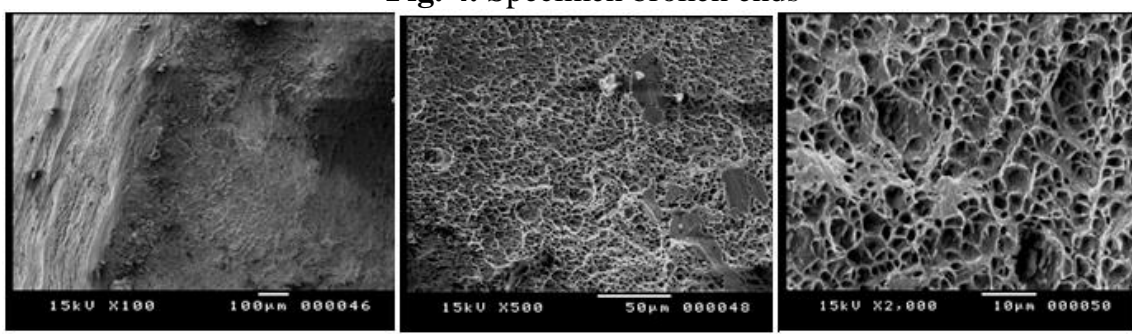

Fig. 5. microstructure of low carbon steel part
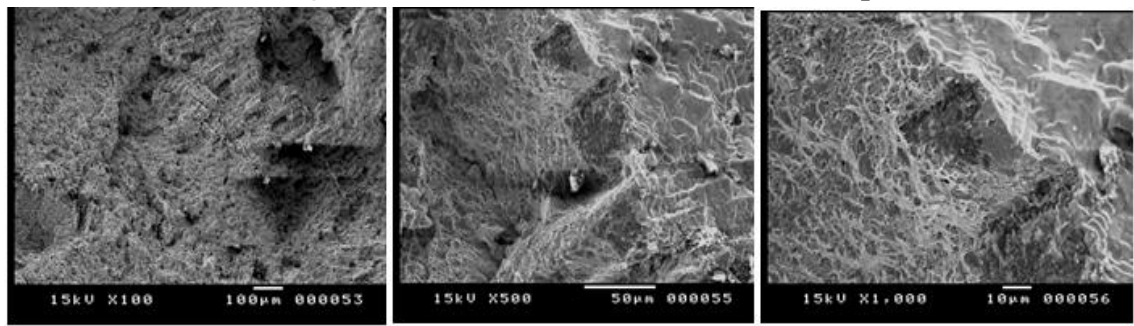

Fig. 6. microstructure of austenitic stainless steel part 


\subsection{Dynamic test}

New innovative method was used in this work to convert SHPB compression wave into a tensile wave using a double wedge action design. The impact tension tests were conducted using regular SHPB consisting of an incident bar and transmitted bar. The SHPB arrangement was loaded using an air operated gun which fires a striker bar with the same diameter of the Hopkinson pressure bars [6]. At the end of the incident bar and the beginning of the transmitted bar installed two cone ends with angle of $11^{\circ}$ to transfer the load smoothly to the specimen and allow suitable margin of reading to represent the load displacement curve of the material.

A tensile specimen installed shown in the fig (7) using nuts in hollow cylinder splited into two halves with its end machined to form cones with the same angles.

The incident wave hits the incident bar cone end and travels through the cone contact of the cones fitted at the end of the Hopkinson bar with the split cylinder cone which tends to widen due to the cone wedge effect. The splited hollow cylinder transfer the compression wave into a tensile wave transmitted through the nuts to the tensile specimen.

The result of stress strain values were obtained from digital oscilloscope with memory was used for recording the strain gauge signals. The strain signals were recorded at the strain gauge stations readings then taken to PC to calculate the load versus displacement using one dimension wave propagation theory and calibration coefficient for the specimen which can be then used to calculate the tensile properties of the specimen shown in Fig (8).

Part of the wave are consumed in fracturing the specimen which is indicated using a special arrangement to measure the time of failure while the other portion are consumed in moving the two halves of the holding cylinder after the specimen failure.

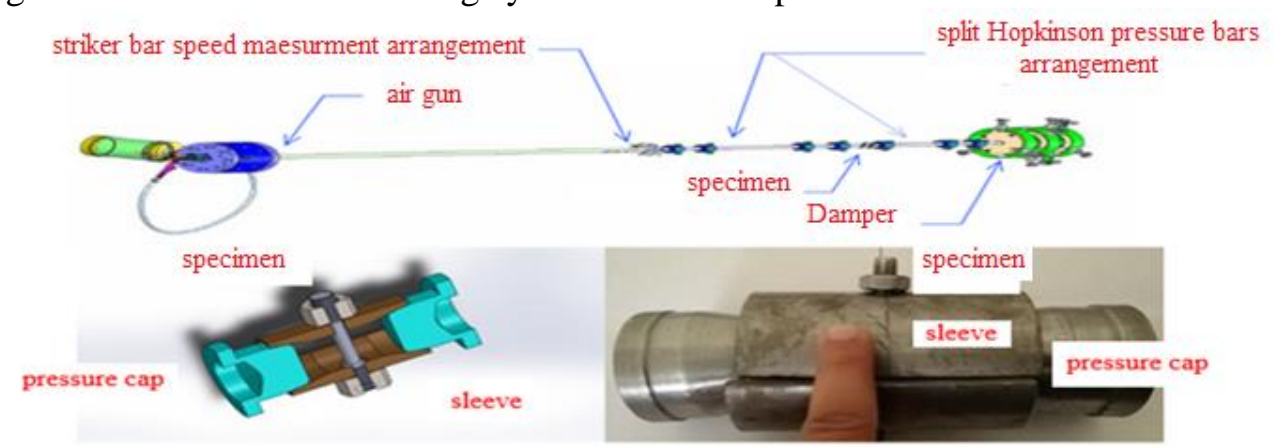

Fig. 7. Tensile split Hopkinson pressure bar
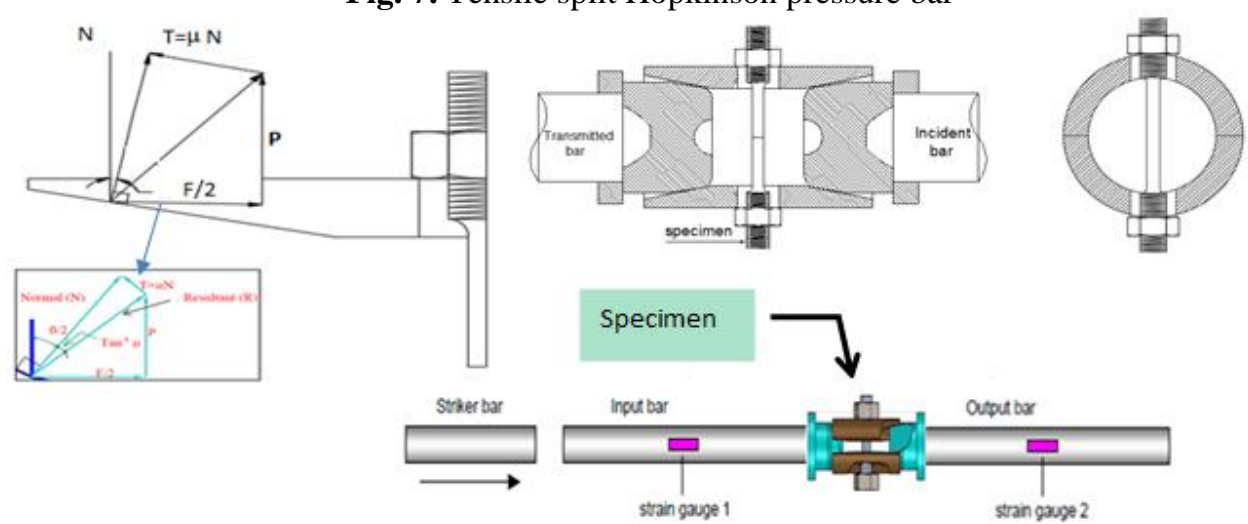

Fig. 8. Specimen is mounted between two halves of a cylinder with a double conical hole 
The incident compression wave transferred into tensile wave affecting the specimen and the relation between cone force and specimen tensile force is given by:

$\mathrm{P}=\frac{\mathrm{F}}{\tan \left[\frac{\beta}{2}+\tan ^{-1} \mu\right]}$

Where:

$\beta$ is the Wedge angle in degrees

$\mathrm{F}$ is the wedge Load in $\mathrm{N}$

$\mu$ is the Coefficient of friction of steel and steel combinations, $\mu$ taken as value of (0.5-0.8) [7]

$\mathrm{P}$ is the axial load in $\mathrm{N}$

$\mathrm{F}=\frac{1}{2} \mathrm{EA}\left[\varepsilon_{\mathrm{i}}(\mathrm{t})+\varepsilon_{\mathrm{r}}(\mathrm{t})+\varepsilon_{\mathrm{t}}(\mathrm{t})\right]$

Where

$A$ is the cross section area of the bars

$\mathrm{E}$ is the Young modulus of the bars material

$\varepsilon_{\mathrm{i}}(t), \varepsilon_{r}(t)$ and $\varepsilon_{t}(t)$ are the incident, reflected and transmitted strain waves respectively. The bars displacement calculated as following:

$\delta(t)=\mu_{I}(t)-\mu_{t}(t)=c_{0} \int_{0}^{t}[\varepsilon i(t)-\varepsilon r(t)-\varepsilon t(t)] . d t$

Where:

$\mathrm{C}_{0}$ is the elastic wave speed in the Hopkinson bars materials $=\sqrt{\frac{E}{\rho}}$

$\mathrm{E}$ is the Young modulus of the incident and transmitted bar material.

$\rho$ is the bars material density and

The net displacement of the specimen can then be determined using the same analysis used in the load analysis.

\section{Results and discussions}

Samples were tested at different loading rates and the signals of the strain gauge stations were recorded and processed to obtain the load and displacement for each test. A sample of the recorded signals is shown in fig (9). The ultimate strength as shown in fig (10) was found to be around $1400 \mathrm{Mpa}$ to $1800 \mathrm{MPa}$. The ultimate strength increase three time in comparison to static test.

The results obtained was in the same range of other previous work for similar combination $[3,4]$.The stress- strain curve show a small elastic response to the dynamic load while plastic deformation take place from the begging of the loading to the failure point. 


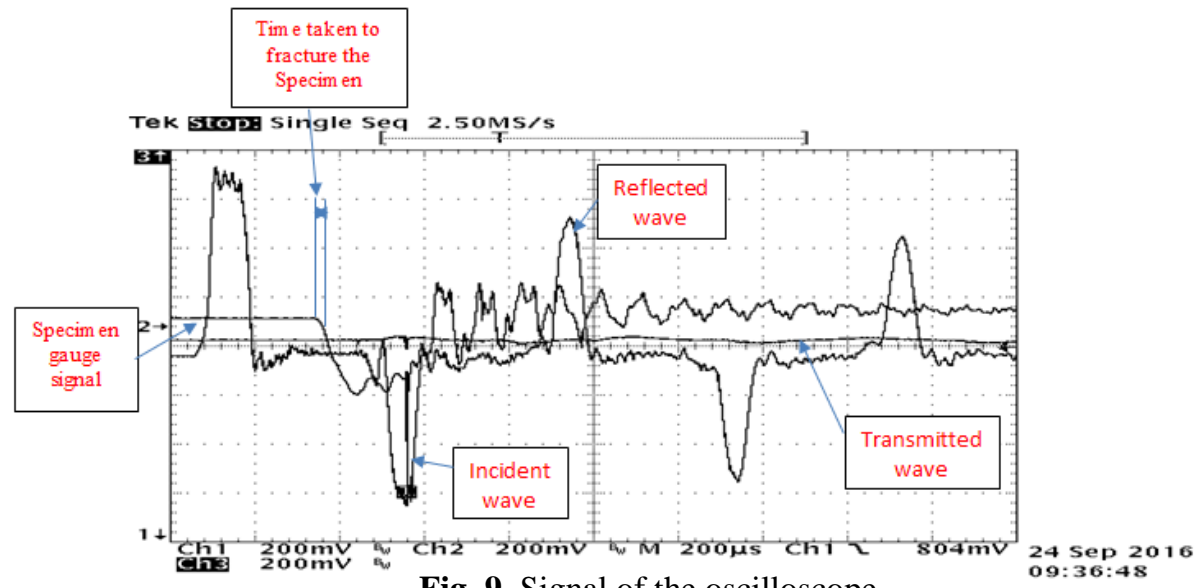

Fig. 9. Signal of the oscilloscope

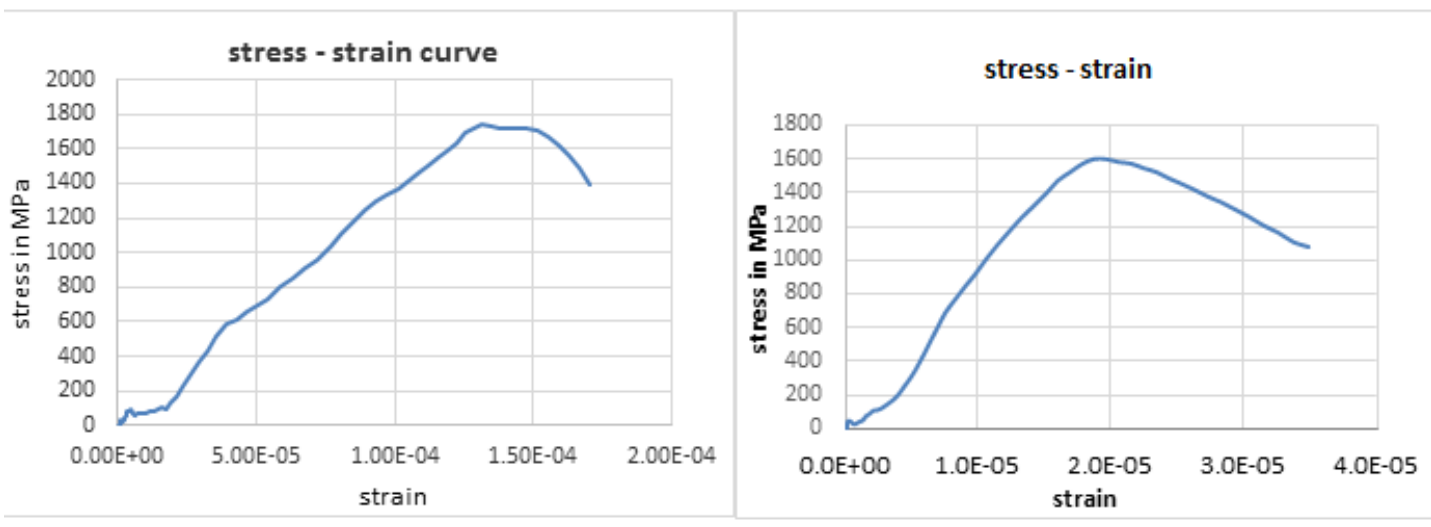

Fig. 10. Stress - strain curves

\section{Microstructure examination}

The fractured specimens were examined at macro and micro scale using both optical an electronic and microscope the fracture zone show a sort of cup and cone formation at macro scale which indicate a ductile fracture behavior as shown in fig (11) the figure shows small dimples including high level of local plastic deformation which indicate a smooth tensile failure characterization of the specimen. The fractured specimen show at the macroscopic scale a cup and cone formation which confirm the ductile fracture.
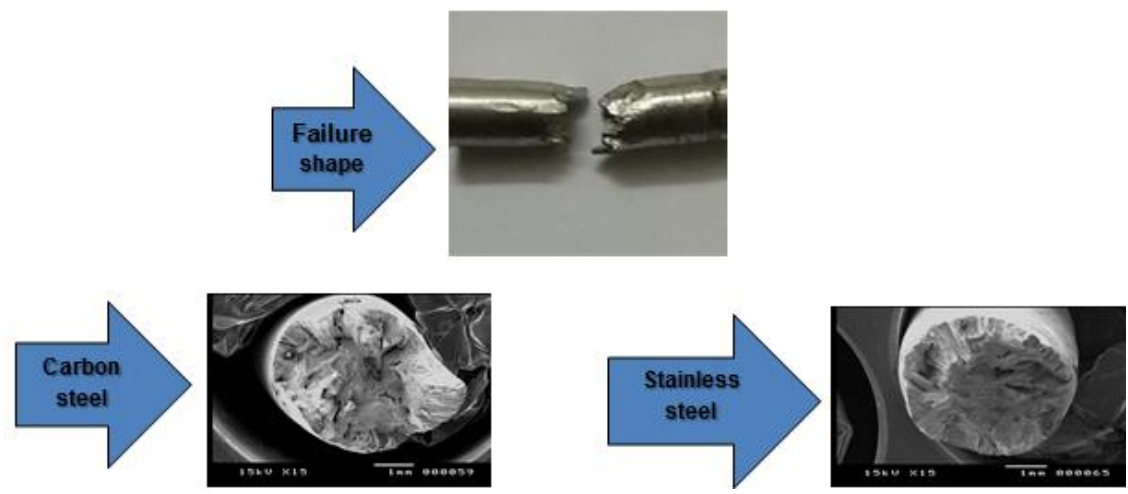

Fig. 11. Failure shape 


\section{Microstructure of specimen}

The inclusion resulting from the welding process between the two alloys have an important effect on the fracture behavior of the junction. Various types of third phase particles such as oxides, carbides and sulfides produce during the welding process. The extent of these phases effect of the strength and fracture behavior of the junction depend on their shape, heat treatment of the specimen. voids and porosity produced during welding process also have a great effect on the test output these can be shown in the figures (12-13) where the cup and cone for low carbon steel half of the specimen show some torsion fracture along with the cup and cone. The fracture surface also show some cleavage fracture at the outer bimetal of the specimen where the hardening effect of the rapid cooling surface produce a more brittle characterize in comparison to the softened welded cone.
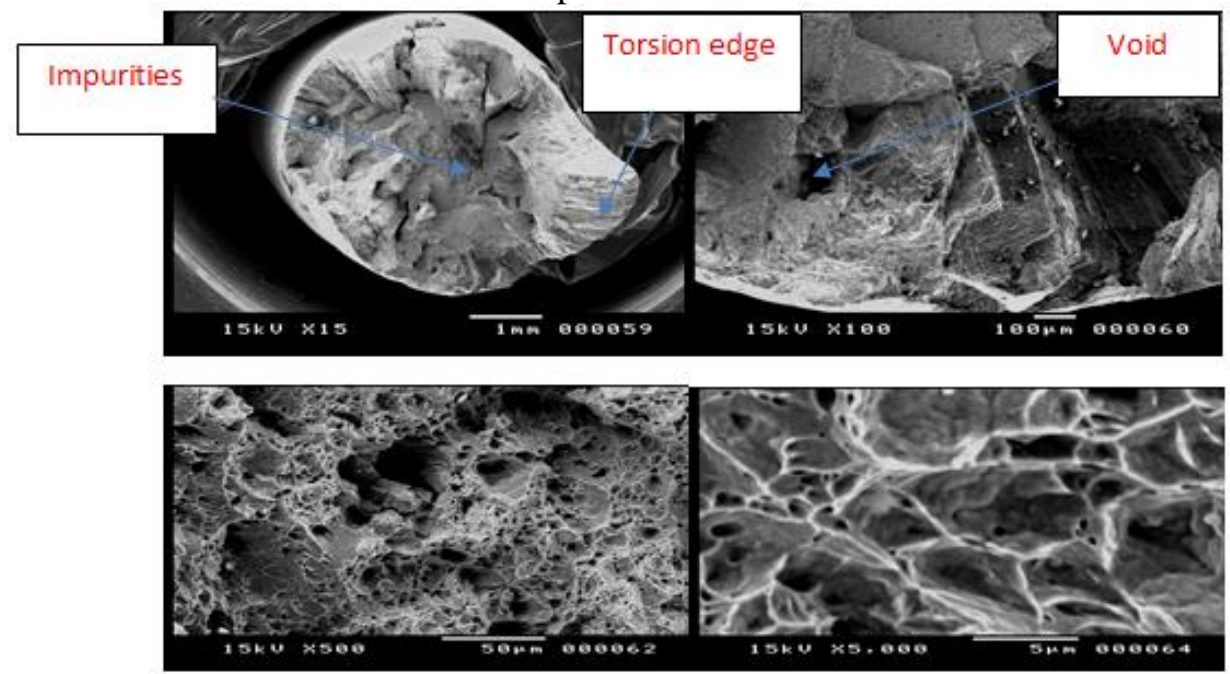

Fig. 12. Carbon steel half
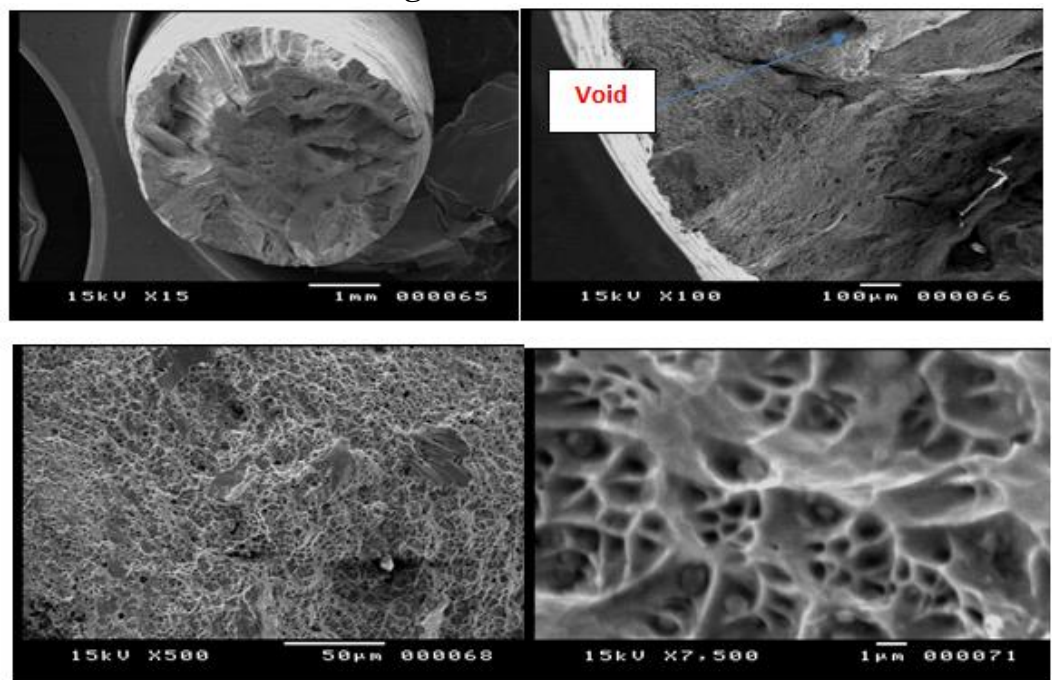

Fig. 13. Stainless steel half 


\section{Conclusion}

New simple method was proposed for measuring the material tensile behavior under high loading rates using a simple modification for SHPB arrangement and the Experimental results of stress - strain values were found to agree with previous work done by other researchers $[3,4]$. the result shows that bimetal junction can resultant up to 3 times of static load in case of dynamic load which indicate the suitability of usage of such junction in process subjected to dynamic load such as water hummer also the ductile nature of the fracture indicate the difficulty of catastrophic brittle fracture of the junction.

\section{References}

[1] Weinong W. Chen · Bo Song, Split Hopkinson (Kolsky) Bar Design, Testing and Applications, 2011.

[2] Lindholm, U. S. and Yeakley, L. M. High strain-rate testing: Tension and compression. experimental Mechanics, 8, 1-9, 1968.

[3] Rotbaum, Y. and D. Rittel, Is There An Optimal Gauge Length for Dynamic Tensile Specimens? experimental Mechanics, 2014. 54(7): p. 1205-1214.

[4] M. Sasso, M.C., G. Newaz, D. Amodio, determining true stress-strain curve by dynamic tensile tests. p. 8, 2004.

[5] Ogawa, k. impact-tension compression test by using a split-Hopkinson bar. Experimental mechanics, 24, 81- 85, 1984.

[6] W. M. Khairaldien, M.R. Bayoumi, A. A. Khalil. Study of the fracture toughness of Powdered manufactured aluminum Matrix composites under different loading rates, 2007.

\section{Works sited}

[1] http://www.engineeringtoolbox.com/friction-coefficients-d 778.html friction coefficient for some common materials and materials combinations , 2015. 


\title{
قياس خصائص الثد لمواد ملحومة غير متثابهة عند معدل اجهاد عالي

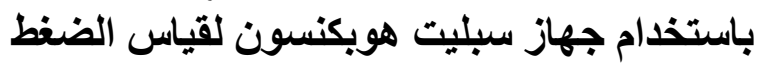

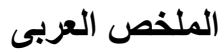

تتطلب التطبيقات الصناعية والإنشائية الحديثة فهم و اضـح لسـلوك المو اد الهندسية تحت حسالات التحميل الديناميكية خاصة بالنسبة للتقاطع مع المو اد الغير منشابهة الإنة

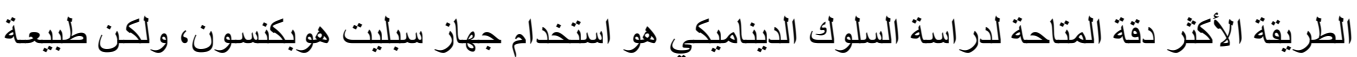

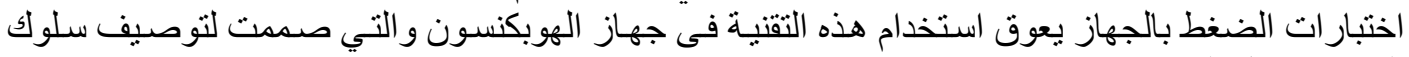

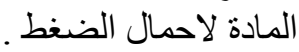

العديد من المحاو لات قدمت لاضافة القدرة لجهاز الاسبليت هوبكنسون لتحميل عينـات باحمـال شد على لئى محورين باستخدام تعديلات مختلفة. بينمـا معظم هذه المحساو لات فثلت في توفير حالـة كافيـة مـن حركة الموجـة وأهملت الفقد النـاجم عن التعديلات الهندسية. في هذا العمل طريقة بسيطة مقدمة تم تتفيذها لإنتاج موجة الثد في جهاز الهوبكنسون و استخدامها لقياس خصائص الثد للمادة. تم تطبيق حمولـة الثـد ذو المحورين بمسـاعدة مخروطين معاكسين لبعضـهـا البعض التي تحسول موجـة

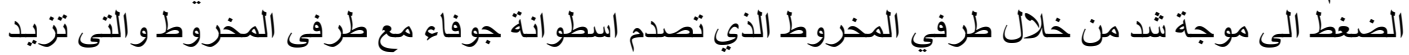

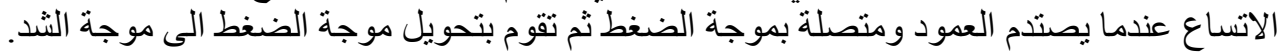

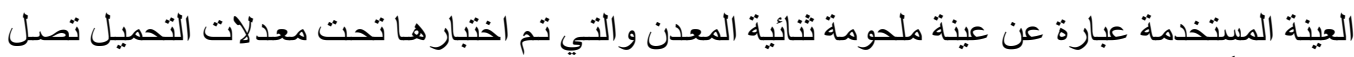

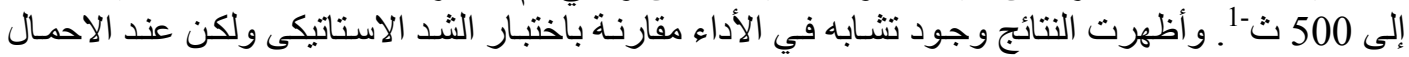

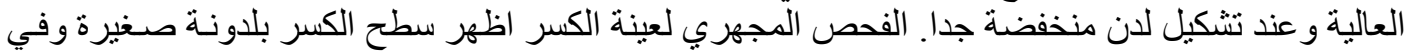

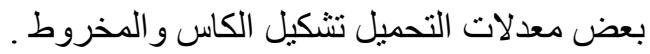

